\title{
KOMPARASI STRUKTUR KOMUNITAS LAMUN DI BANTAYAN KOTA DUMAGUETE FILIPINA DAN DI TANJUNG MERAH KOTA BITUNG INDONESIA
}

\author{
(Comparison Of Community Structure Seagrasses In Bantayan, Dumaguete City \\ Philippines And In Tanjung Merah, Bitung City, Indonesia)
}

\author{
Anas Niko Robetson Sauyai ${ }^{1}$, Billy Theodorus Wagey ${ }^{1}$, Grevo Soleman Gerung ${ }^{1}$ \\ 1. Program Studi IImu Kelautan, Fakultas Perikanan dan IImu Kelautan, Universitas Sam \\ Ratulangi, Manado \\ *e-mail : anasnicko@gmail.com
}

Seagrass is a single seed plants (monocots) of the class Angiospermae. These plants have adapted to live immersed in the sea. Seagrass consists of a rhizome or rhizome (root rhizome or stem sunset), leaves and roots. The area of Bantayan waters, Dumaguete City and Tanjung Merah waters are different geographic location, but both have seagrass, therefore, it is necessary to study in order to provide scientific information on the seagrass beds. This study aims to assess the community structure of seagrass in the waters. Data I was collected in the area of seagrass both sites with an area of each area of $50 \times 100$ or $5000 \mathrm{~m} 2$ ( 0.5 ha) by using the quadrant $50 \times 50 \mathrm{~cm}$ on the third transect line. Eight species of seagrasses were found in the waters of Bantayan while in the waters of the Tanjung Merah seven Species. Seagrass density values in the waters of Bantayan is 0.4448 whereas in the waters of the Tanjung Merah is 0.3464 (the highest density in the waters of Bantayan). Extensive seagrass cover in the waters of Bantayan $0.00378 \%$ while in the waters of Tanjung Merah $0.00372 \%$. Diversity index $\left(\mathrm{H}^{\prime}\right)$ of seagrass in the waters of Bantayan is 0.8574 whereas in Tanjung Merah is 0.7074 . These results showed that the diversity of seagrass in Bantayan waters is higher than those from Tanjung Merah waters.

Keywords : Comparison, Seagrass community structure, Dumaguete, Tanjung Merah

Lamun adalah tumbuhan berbiji tunggal (monokotil) dari kelas Angiospermae. Tumbuhan ini telah menyesuaikan diri untuk hidup terbenam di dalam laut. Lamun terdiri dari rhizome atau rhizoma (batang terbenam atau akar rimpang), daun dan akar. Perairan Bantayan, Kota Dumaguete dan perairan Tanjung Merah berbeda letak geografis, tetapi sama-sama memiliki padang lamun, sehingga perlu dilakukan penelitian dalam rangka menyediakan informasi ilmiah mengenai padang lamun tersebut. Penelitian ini bertujuan untuk mengkaji struktur komunitas lamun di kedua perairan tersebut. Pengambilan data dilakukan di daerah padang lamun kedua lokasi penelitian dengan luas masing-masing area $50 \times 100$ atau $5000 \mathrm{~m}^{2}(0,5 \mathrm{Ha})$ dengan menggunakan kuadran $50 \times 50 \mathrm{~cm}$ pada 3 line transek. Hasil penelitian diperoleh sebanyak 8 spesies lamun di perairan Bantayan sedangkan di perairan Tanjung Merah diperoleh 7 spesies. Nilai kepadatan lamun di perairan Bantayan yaitu 0,4448 sedangkan di perairan Tanjung Merah adalah 0,3464 (kepadatan tertinggi di perairan Bantayan). Luas tutupan lamun di perairan Bantayan 0,00378 \% sedangkan di perairan Tanjung Merah 0,00372\%. Indeks keanekaragaman $\left(\mathrm{H}^{\prime}\right)$ lamun di perairan Bantayan yaitu 0,8574 sedangkan di Tanjung Merah 0,7074 , dari hasil ini menujukkan bahwa keanekaragaman lamun di perairan Bantayan lebih tinggi dari perairan Tanjung Merah.

Kata kunci : Komparasi, Struktur komunitas Lamun, Dumaguete, Tanjung Merah 


\section{PENDAHULUAN}

Lamun (seagrass) atau disebut juga ilalang laut, adalah salah satu kelompok tumbuhan hidup di perairan dangkal hingga pada kedalaman 50 $60 \mathrm{~m}$ (Nybakken, 1988), bahkan mencapai 90 m (Dahuri, 2003), namun melimpah di daerah pasang surut. Lamun tumbuh subur pada daerah terbuka pasang surut dan perairan pantai atau goba yang dasarnya berupa lumpur, pasir, kerikil dan patahan karang mati dengan kedalaman sampai 4 m (den Hartog, 1970; Dahuri, 2003).

Lamun mempunyai beberapa sifat yang memungkinkannya hidup di lingkungan laut, yaitu: mampu hidup di media air asin, mampu berfungsi normal dalam kondisi terbenam, mempunyai sistem perakaran jangkar yang berkembang baik, mampu melakukan penyerbukan dan daun generatif dalam keadaan terbenam (den Hartog, 1970; Asriyana dan Yuliana, 2012). Lamun tumbuh dengan baik di daerah yang terlindung dan bersubstrat pasir, stabil dekat sedimen yang bergerak secara horizontal (Hutomo et al, 1988 dalam Kordi, 2011).

\section{METODE PENELITIAN}

Penelitian ini dilaksanakan di Bantayan, Kota Dumaguete, Filipina (Gambar 1) ( $9^{0} 19^{\prime} 52,51^{\prime \prime}$ LU dan $123^{\circ}$ 18' 36,15" BT) dan Tanjung Merah, Kota Bitung, Indonesia (Gambar 2) $\left(1^{0}\right.$ $23^{\prime} 43,00^{\prime \prime}$ LU dan $125^{\circ} 6^{\prime}$ 43,53" BT).

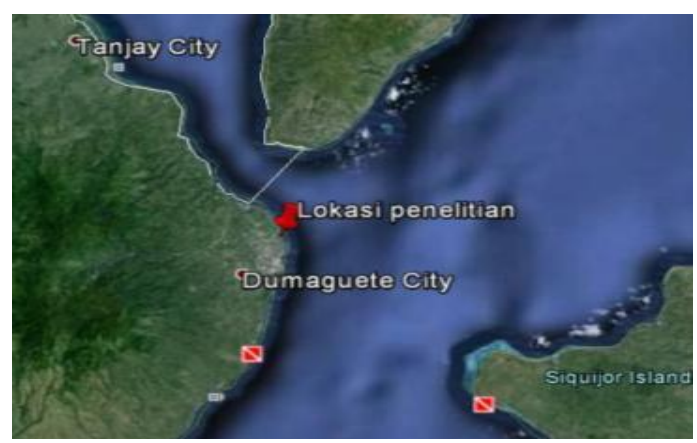

Gambar. 1. Bantayan ( Filipina)

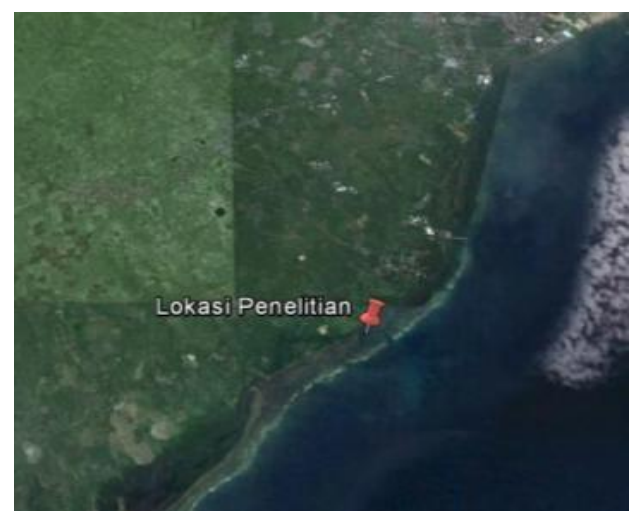

Gambar.2. Tanjung Merah

(Indonesia)

Penelitian ini dilaksanakan selama empat setengah bulan (Maret - Juni 2014), untuk di perairan Bantayan dilaksanakan Agustus 2013.

Pengambilan sampel lamun dilakukan dengan menggunakan metode garis transek (line transect) dengan teknik sampling kuadrat (Krebs, 1999 dalam Wagey, 2013). Transektransek dengan jarak tertentu diletakkan tegak lurus terhadap garis pantai. Di setiap transek ditempatkan kuadran-kuadran dengan jarak 5 meter antar kuadran. Semua lamun yang terdapat dalam setiap kuadran, diangkat dari substratnya, dibersihkan, dan selanjutnya dimasukkan ke dalam kantong plastik.

Pertama garis transek sepanjang 50 meter ditarik tegak lurus dengan garis pantai di masing-masing stasiun dengan jarak antar tiap stasiun 50 meter pada kedua lokasi penelitian. Kemudian kuadran yang berukuran 50 x $50 \mathrm{~cm}$ diletakkan dengan jarak 5 meter sepanjang garis transek, lalu dilihat luas tutupan lamun, jumlah jenis yang ada dan dicatat menggunakan white sheet dan pensil 2B yang telah disediakan. Sampel lamun yang berada pada kuadran diambil dan difoto kemudian diidentifikasi.

Data parameter lingkungan yang diambil meliputi suhu dan salinitas. Suhu perairan diukur menggunakan termometer sedangkan salinitas menggunakan salinometer. Data arus 
dan intensitas cahaya tidak diambil karena kedua lokasi penelitian merupakan daerah pasang surut dengan kedalaman sekitar 1-2 meter. Pergerakan arus mengikuti pasang surut air laut, dan cahaya matahari menembus seluruh bagian perairan dimana lamun tumbuh dan melakukan proses fotosintesis dengan baik.

\section{HASIL DAN PEMBAHASAN}

Pada kedua lokasi penelitian yaitu lokasi perairan Bantayan, Kota Dumaguete, Filipina ditemukan sebanyak 6 genus, 8 spesies yaitu genus Cymodocea: Cymodocea serrulata, Cymodocea rotundata, genus Halophila: Halophila ovalis, genus Thalassia: Thalassia hempricii, genus Halodule: Halodule uninervis, Halodule pinifolia, genus Syringodium: Syringodium isoetifolium dan genus Enhalus: Enhalus acroides. sedangkan di perairan Tanjung Merah, Kota Bitung, Indonesia ditemukan 6 genus, 7 spesis yaitu genus Cymodocea: Cymodocea rotundata, genus Halophila: Halophila ovalis, genus Thalassia: Thalassia hempricii, genus Halodule: Halodule uninervis, Halodule pinifolia, genus Syringodium: Syringodium isoetifolium dan genus Enhalus: Enhalus acroides.

Perbedaannya hanya pada 1 spesis yaitu $C$. serrulata yang hanya ditemukan di perairan Bantayan. Hal ini juga mempengaruhi jumlah total individu yang didapat sehingga terlihat lebih tinggi nilainya di Bantayan dari pada di Tanjung Merah.

\section{Kepadatan}

Spesies lamun di perairan Bantayan yang memiliki nilai kepadatan dan kepadatan relatif tertinggi yaitu $C$. rotundata 0,1184 dan terendah adalah $H$. ovalis 0,0400 , sedangkan di perairan Tanjung Merah yang tertinggi yaitu spesis $T$. hempricii 0,2448 dan terendah adalah $H$. pinifolia 0,0176 .
Nilai kepadatan dan kepadatan relatif lamun kedua lokasi jika dibandingkan maka untuk perairan Bantayan memiliki total nilai kepadatan 0,8896 sedangkan di perairan Tanjung Merah 0,6928. Lamun hidup di perairan yang dangkal dan jernih dengan sirkulasi air yang baik. Lamun tumbuh subur terutama di daerah pasang surut dan perairan pantai yang dasarnya berupa lumpur, pasir, kerikil dan patahan karang mati dengan kedalaman 4 meter dalam perairan yang sangat jernih (Asriyana dan Yuliana, 2012).

\section{Tutupan}

Lamun di kedua lokasi penelitian ini memiliki nilai tutupan yang berbeda dan bervariasi pada tiap kuadrannya di 3 line transek dengan luasan area yang sama yaitu $5000 \mathrm{~m}^{2}$ atau $0,5 \mathrm{Ha}$, dimana nilai tutupan tertinggi yaitu di perairan Bantayan adalah 0,00378 \% sedangkan di perairan Tanjung Merah $0,00372 \%$. Tutupan lamun di kedua lokasi penelitian ini berada pada substrat berpasir, untuk di perairan Tanjung Merah di line transek pertama ada juga terdapat substrat pasir yang agak berlumpur (pasir berlumpur).

Penelitian di perairan Bantayan dilakukan ketika air pasang sehingga untuk melihat tutupan lamun lebih mudah karena daun lamun berdiri tegak. Sebaliknya di Tanjung Merah penelitian dilakukan ketika air surut sehingga untuk melihat tutupan lamun harus lebih teliti karena daun lamun tidak berdiri tegak dan daun menutupi substrat sehingga terlihat tutupannya tinggi padahal tidak demikian.

\section{Keanekaragaman}

Keanekaragaman lamun di kedua lokasi penelitian yaitu di perairan Bantayan 8 spesies dan di Tanjung Merah 7 spesies, Ini menunjukkan bahwa padang lamun di kedua lokasi penelitian tergolong vegetasi campuran. Menurut Kordi (2011), bahwa padang lamun dapat 
Tabel 1. Keanekaragaman lamun di perairan Bantayan.

\begin{tabular}{|c|c|c|c|c|}
\hline No & Jenis & $\begin{array}{c}\mathrm{Pi} \\
(\mathrm{ni} / \mathrm{N})\end{array}$ & $\begin{array}{c}\log \mathrm{Pi} \\
\log (\mathrm{ni} / \mathrm{N})\end{array}$ & $\mathrm{H}^{\prime}$ \\
\hline 1 & $\mathrm{Cr}$ & 0,1916 & $-0,7174$ & $\begin{array}{c}- \\
0.1375\end{array}$ \\
\hline 2 & $\mathrm{Ho}$ & 0,2217 & $-0,6542$ & $\begin{array}{c}- \\
0,1450\end{array}$ \\
\hline 3 & Th & 0,3533 & $-0,4517$ & $\begin{array}{c}- \\
0,1596\end{array}$ \\
\hline 4 & $\mathrm{Hu}$ & 0,0461 & $-1,3354$ & $\begin{array}{c}- \\
0,0616\end{array}$ \\
\hline 5 & $H p$ & 0,0254 & $-1,5950$ & $\begin{array}{c}- \\
0,0405\end{array}$ \\
\hline 6 & Si & 0,0323 & $-1,4903$ & $\begin{array}{c}- \\
0,0481\end{array}$ \\
\hline 7 & $E a$ & 0,1293 & $-0,8882$ & $\begin{array}{c}- \\
0,1148\end{array}$ \\
\hline & & & & $\stackrel{-}{0,7074}$ \\
\hline \multicolumn{4}{|c|}{ Keanekaragaman ( $\left.\mathrm{H}^{\prime}\right)$} & 0,7074 \\
\hline
\end{tabular}

membentuk vegetasi tunggal, jika tersusun atas satu jenis yang tumbuh membentuk padang lebat, sedangkan vegetasi campuran terdiri dari $2-12$ jenis lamun yang tumbuh bersamasama pada satu substrat. Keanekaragaman lamun tertinggi terdapat di daerah Indo-Pasifik dengan 7 genera dan 25 spesis, 12 di antaranya dijumpai di perairan Indonesia (den Hartog, 1970; Supriharyono, 2000). Nilai tertinggi keanekaragaman lamun di perairan Bantayan yaitu spesis $C$. rotundata dan terendah adalah $H$. ovalis, sedangkan di perairan Tanjung Merah nilai keragaman tertinggi yaitu spesis $T$. hempricii dan terendah adalah $H$. pinifolia, sedangkan untuk indeks keanekaragaman perairan Bantayan lebih tinggi dibandingkan di perairan Tanjung Merah (Tabel 1 dan 2).
Tabel 2. Keanekaragaman lamun di perairan Tanjung Merah.

\begin{tabular}{|c|c|c|c|c|}
\hline $\begin{array}{l}\mathrm{N} \\
\mathrm{O}\end{array}$ & Jenis & $\begin{array}{c}\mathrm{Pi} \\
(\mathrm{ni} / \mathrm{N})\end{array}$ & $\begin{array}{c}\log \mathrm{Pi} \\
\log \\
(\mathrm{ni} / \mathrm{N})\end{array}$ & $\mathrm{H}^{\prime}$ \\
\hline 1 & Cs & 0,1331 & $-0,8758$ & $-0,1166$ \\
\hline 2 & $\mathrm{Cr}$ & 0,2356 & $-0,6278$ & $-0,1479$ \\
\hline 3 & $\mathrm{Ho}$ & 0,0450 & $-1,3471$ & $-0,0606$ \\
\hline 4 & $T h$ & 0,1151 & $-0,9389$ & $-0,1081$ \\
\hline 5 & $\mathrm{Hu}$ & 0,1223 & $-0,9126$ & $-0,1116$ \\
\hline 6 & $H p$ & 0.1421 & $-0,8474$ & $-0,1204$ \\
\hline 7 & Si & 0,1601 & $-0,7957$ & $-0,1274$ \\
\hline \multirow[t]{2}{*}{8} & $\mathrm{Ea}$ & 0,0468 & $-1,3301$ & $-0,0622$ \\
\hline & & & & $-0,8547$ \\
\hline \multicolumn{4}{|c|}{ Keanekaragaman (H') } & 0,8547 \\
\hline
\end{tabular}

Keterangan :

$C s=C$. serrulata

$\mathrm{Cr}=\mathrm{C}$. rotundata

$\mathrm{Ho}=\mathrm{H}$. ovalis

$T h=T$. hempricii

$H u=H$. Uninervis

$H p=H$. pinifolia

$\mathrm{Si}=\mathrm{S}$. isoetifolium

$E a=E$. acroides

\section{KESIMPULAN}

Berdasarkan penelitian ini didapat beberapa kesimpulan bahwa Komunitas lamun di perairan Bantayan diperoleh dari 8 spesies sedangkan di Tanjung Merah bejumlah 7 spesies dari jenis yang sama, hanya jenis $C$, serrulata yang terdapat di perairan Bantayan. Nilai kepadatan lamun di perairan Bantayan adalah 0,8896 sedangkan di perairan Tanjung Merah 0,6928 (kepadatan tertinggi di perairan Bantayan).

Luas tutupan lamun lebih tinggi di perairan Bantayan yaitu 0,00378\% 
sedangkan di perairan Tanjung Merah $0,00372 \%$. Indeks keanekaragaman $\left(\mathrm{H}^{\prime}\right)$ lamun di perairan Bantayan 0,8574 sedangkan di Tanjung Merah 0,7074 , dengan jenis yang sama tetapi spesies $C$. serrulata yang hanya ada di perairan Bantayan.

\section{DAFTAR PUSTAKA}

Asriyana, dan Yuliana. 2012. Produktivitas Perairan. Bumi Aksara. Jakarta..

den Hartog. 1970. The Seagrasses of the World. North Holland Publishing, Amsterdam. 275 pp.

Dahuri, R. 2003. Keanekaragaman Hayati Laut:Aset Pembangunan Berkelanjutan Indonesia. Jakarta. Gramedia Pustaka Utama.

Kordi, M. 2011. Ekosistem Padang Lamun Seagrass. Rineka Cipta. Jakarta. 8-26 hal.

Nybakken, J.W. 1988. Biologi Laut Suatu Pendekatan Ekologis. Gramedia, Jakarta.

Supriharyono, 2000. Pelestarian dan Pengelolaan Sumber Daya Alam di Wilayah Pesisir Tropis. Gramedia Pustaka Utama.

Wagey, B.Th. 2013. Hilamun (Seagrass). Sam Ratulangi University Press. Manado 